\title{
Impact of eyestalk ablation on androgenic gland activity in the freshwater crab Travancoriana schirnerae Bott, 1969 (Decapoda: Gecarcinucidae)
}

\section{Latha Nadkandi Padmanabhan and Sudha Devi Arath Raghavan*}

Department of Zoology and Research Centre, Mary Matha Arts and Science College, Mananthavady, Wayanad, Kerala, India 670 645.*Email: arsudhadevi@gmail.com.

\begin{abstract}
The current study investigated the impact of eyestalk ablation on androgenic gland activity in the freshwater crab Travancoriana schirnerae Bott, 1969 (Decapoda: Gecarcinucidae). Bilateral eyestalk ablation during active phase (March-June) induced hypertrophy and hyperplasia of the gland as evidenced by increased width of the gland, thickness of the connective tissue layer, increase in cell and nuclear diameter with predominance of type I cells. This hypertrophy and hyperplasia was not followed by secretory activity during active phase which possibly suggests the non-functional nature of hypertrophy and hyperplasia. Unilateral destalkation during active phase neither caused hypertrophy nor hyperplasia of the gland cells probably because these crabs may still receive the inhibitory principle from the remaining intact eyestalk causing the gland to remain analogous to that of the unablated controls. The androgenic gland of control crabs during revival phase (JanuaryFebruary) was discerned with a few patches of proliferated type I cells scattered among vacuoles and degenerating cells. The most prominent feature of the gland of bilaterally ablated crabs during revival phase was the extensive proliferation of type I cells. Not much significant change was observed in the morphology and histology of the gland of unilaterally ablated crabs of revival phase.
\end{abstract}

Keywords: Androgenic gland; Eyestalk ablation; Freshwater crab; Histology; Hyperplasia; Hypertrophy.

\section{Introduction}

In male crustaceans, the endocrine and gametogenic functions are clearly separated into distinct organs: the androgenic gland (AG) and the testis, respectively (Ginsburger-Vogel and Charniaux-Cotton, 1982; Charniaux-Cotton and Payen, 1988). The androgenic gland regulates male differentiation, inhibits female differentiation and controls primary
Received

April 3, 2016

Accepted

June 12, 2016

Released

June 30, 2016

Corrected

December 30, 2016

Open Acess

Full Text Article

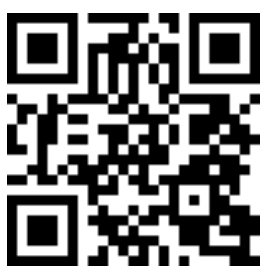

ORCIID

(ㄱ) 0000-0002-7390-9659

Latha Nadkandi

Padmanabhan

(ㄷ) 0000-0003-4062-8073

Sudha Devi Arath Raghavan 
(Thampy and John, 1972; Katakura, 1984; Fowler and Leonard, 1999; Sun et al., 2000; Erkan et al., 2010). Very few studies are available on structural aspects of the AG in freshwater crabs. Joshi and Khanna (1987) recorded the variation in size, structure and activity of AG in relation to the male reproductive cycle of the freshwater crab Potamon koolooense. Devi and Smija (2014) described the seasonal changes in the structure and secretory activity of AG in Travancoriana schirnerae.

The AG secretes a hormone called the androgenic gland hormone (AGH) which regulates sex determination in crustaceans. Adiyodi and Adiyodi (1970) and Fingerman (1997) reported that AGH controls the differentiation of male genital apparatus and secondary sexual characteristics. The secretion of AGH from the AG is regulated by the gonad inhibiting hormone (GIH) released from the X-organ sinus gland (XO-SG) complex of the eyestalks. Unlike females, the action of GIH appears to be indirect in males via a direct effect on the AG (Adiyodi, 1984; Gupta et al., 1989; Hasegawa et al., 1993). Studies on the role of eyestalk hormones on testicular and AG activity in the Australian red claw crayfish Cherax quadricarinatus revealed that the sinus gland controls the activity of the AG suggesting an endocrine axis-like relationship between the sinus gland, AG and the male reproductive system in decapods (Khalaila et al., 2002).

Literature is plenty regarding the effect of eyestalk ablation on the activity of AG of marine decapods. Demeusy (1960) investigated the role of eyestalks in the differentiation of genital organs in the shore crab Carcinus maenas. The impact of eyestalk ablation on AG activity in the protandric shrimp Pandalus platyceros was reported by Hoffman (1968) and Foulks and Hoffman (1974). In immature crabs Callinectes sapidus and Rhithropanopeus harrisii and adult penaeid Parapenaeopsis hardwickii, Payen et al. (1971) and Kulkarni et al. (1984) observed the effects of bilateral destalkation on AG activity. Choy (1987) noticed activation of the AG in eyestalk ablated penaeid Penaeus canaliculatus. In mature males of the swimmer crab Portunus pelagicus bilateral eyestalk ablation produced hypertrophy of the AG (Sroyraya et al., 2010). Chung et al. (2011) confirmed the presence of a possible endocrine axis between the eyestalk ganglia and the AG in adult $C$. sapidus. Quantitative analysis of the AG in destalked Litopenaeus vannamei during moult stages was reported by Vázquez-Islas et al. (2015).

Few studies have investigated the impact of eyestalk ablation on AG activity in freshwater decapods, in particular crabs. Eyestalk ablation experiments in Paratelphusa hydrodromous evidenced increased size and histological changes in the AG (Adiyodi, 1984). Sarojini and Gyananath (1985) recorded the seasonal variations and the role of neurosecretory hormones on AG of the prawn Macrobrachium lamerrii. Taketomi et al. (1997) reported highly active AG in the eyestalk ablated shrimp Neocaridina denticulata. Kim et al. (2002) observed the effects of eyestalk ablation on protein synthesis of AG and gonad development in reproductive and non-reproductive adult males of $M$. nipponense. Phoungpetchara et al. (2011) and Revathi et al. (2013) observed hypertrophied AG in bilaterally destalked $M$. rosenbergii. The present attempt has been made to evaluate the impact of unilateral and bilateral eyestalk ablation during active and revival phases of the AG in the freshwater crab T. schirnerae.

\section{Materials and methods}

Eyestalk ablation was performed during the revival and active phases of the gland. Adult intermoult male crabs of carapace width 4.0-5.0 $\mathrm{cm}$ were collected from the paddy fields of Ondayangadi, about $5 \mathrm{~km}$ northeast of Mananthavady $\left(11.82^{\circ} \mathrm{N}\right.$ and $76.02^{\circ} \mathrm{E}$, altitude $\left.767 \mathrm{~m}\right)$ in Wayanad district of Kerala, India. The experimental study commenced after acclimatization of crabs to laboratory conditions for four days. Thirty crabs were randomly divided into three groups of 10 each. Group I comprised of unilaterally eyestalk ablated (-E1) crabs; Group II comprised of bilaterally eyestalk ablated 
(-E2) crabs and Group III had unablated, eyestalk intact crabs which served as controls. The right eyestalks of Groups I and II were carefully ablated from the base using sterile surgical scissors and cauterized immediately with a hot and blunt needle to prevent excessive loss of haemolymph. To minimize the shock of ablation, the left eyestalks of Group II crabs were ablated a day later. The crabs were fed ad libitum with boiled egg and pulses and maintained separately in plastic troughs throughout the experimental period.

On 15th day, both control and experimental crabs were sacrificed. The AG along with the posterior vas deferens were dissected out under a Trinocular stereo zoom microscope and fixed in Bouin's fluid. The tissues were dehydrated in ethanol series, cleared in xylene and embedded in paraffin wax. Sections of 5 $\mu \mathrm{m}$ thickness were cut using a rotary microtome and stained with haematoxylineosin. The histological features were examined and photographed with a Leica DM 500 Research Microscope equipped with a DG 330/210 camera, using Biowizard software. The diameter of AG cells and their nuclei were measured using Biowizard software. The number of cells belonging to each cell type was counted in seven visual fields to determine the major cell type in the AG of control and experimental crabs during active, inactive and revival phases. From each field 60 cells were counted, totaling 420 cells per specimen.

\section{Results}

The gland was found active from March to June (active phase) and entered a period of rest extending from August to December (inactive phase). The activities of the gland were found revived during January-February (revival phase).

\section{Histology of androgenic gland of control crabs during active phase (March-June)}

The AG appeared as a thin, elongated thread-like structure attached firmly on the wall of the PVD, enveloped by a layer of connective tissue $(20.23 \pm 1.90$ $\mu \mathrm{m})$ (Figure 1A). The gland measured $244.40 \pm 56.35 \mu \mathrm{m}$ in width. Based on cell size, relative proportion of nuclei and presence or absence of vacuoles, three cell types could be distinguished in the gland: type I, type II and type III.

Type I cells: Small, oval, compactly arranged cells $(6.0-12.4 \mu \mathrm{m})$ with relatively large (3.6-7.3 $\mu \mathrm{m})$ and mildly basophilic cytoplasm (Figure 1B). These cells had distinct cell boundaries and nuclear membranes. Their nuclei appeared highly basophilic, placed mostly in the centre, but peripheral arrangement was also observed. Small, round and highly basophilic nucleoli (1-3) were seen arranged centrally or peripherally, close to the nuclear membrane. The granular chromatin was seen homogenously distributed in the nucleoplasm. The nucleoprotoplasmic ratio (NPR) of type I cells was very high (0.47-0.84).

Type II cells: Polygonal cells (12.8$23.5 \mu \mathrm{m})$, formed the major cell type in the AG of control crabs during the active phase (Figure 1C). Their nuclei $(2.4-6.2 \mu \mathrm{m})$ were round or oval, peripherally or centrally located with distinct nuclear membranes. The NPR was recorded in the range $0.17-0.40$, lesser than that of type I cells. Chromatin was moderately basophilic and showed a granular appearance. Nucleoli (1-3) appeared small, round, highly basophilic with a central or peripheral location. Type II cells enclosed more amount of moderately basophilic cytoplasm than type I cells.

Type III cells: Large cells (10.8$18.5 \mu \mathrm{m})$ with distinct cell and nuclear membranes. Less in number compared to the other two cell types and was found only during the active phase (Figure 1D). Their nuclei were elongated, measuring 2.60-3.90 $\mu \mathrm{m}$ in diameter with condensed chromatin. The cytoplasm of these cells appeared transparent and vacuolated. The NPR was found very low (0.14-0.28). All the three cell types were perceptible in AG of control crabs during active phase. The cells were compact with sharp boundaries and without intercellular spaces. Type II cells were the most dominant cell type $(65.40 \pm 3.84 \%)$; type I and type III cells constituted $22.60 \pm 2.70 \%$ and $12.00 \pm 1.58 \%$ of the cell population, respectively (Figure 2). 

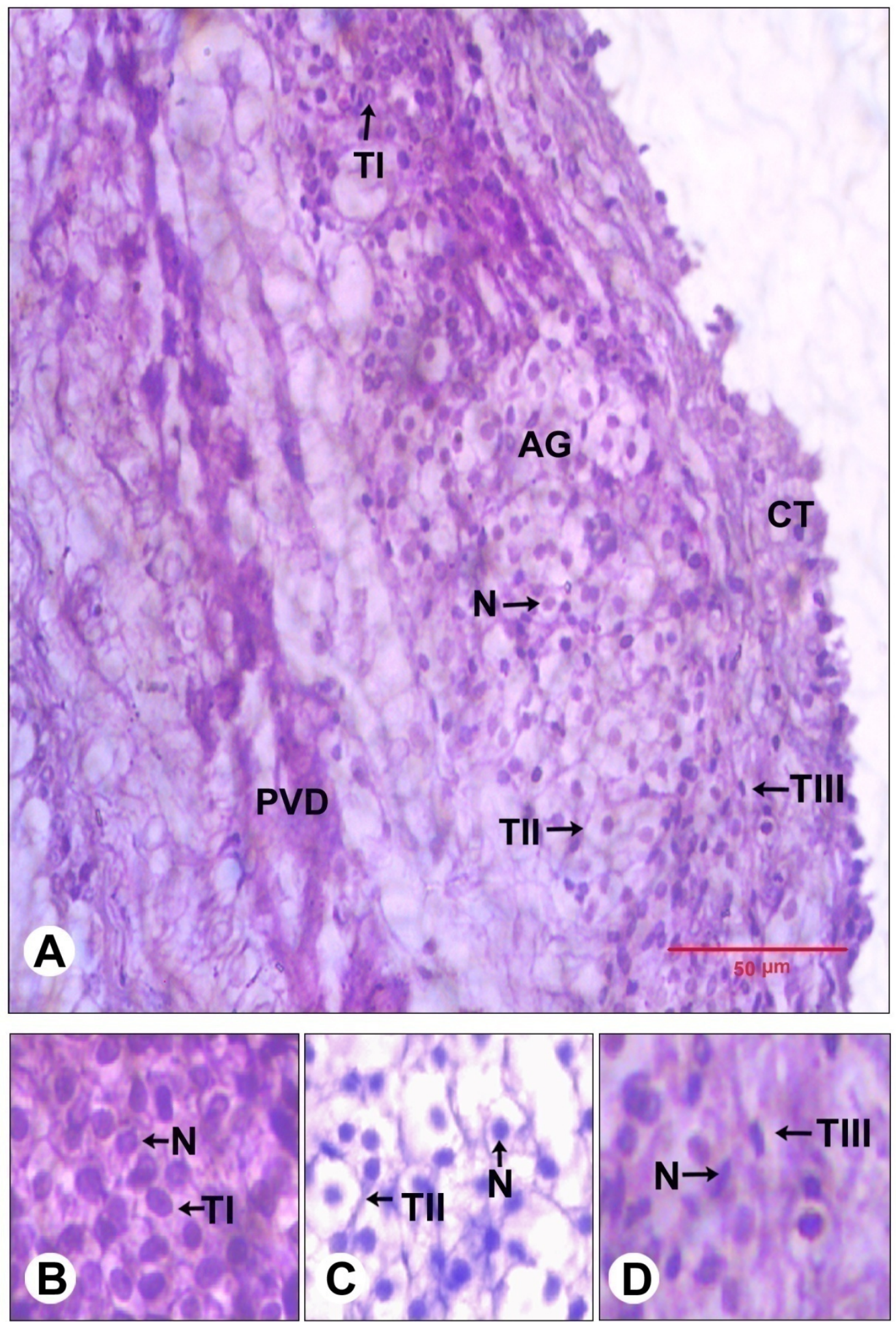

Figure 1. Histology of androgenic gland of control crabs during active phase (June). (A) Androgenic gland showing type I, type II and type III cells, (B) Type I cells, (C) Type II cells, (D) Type III cells. AG: Androgenic gland; CT: Connective tissue layer; N: Nucleus; PVD: Posterior vas deferens; TI: Type I cell; TII: Type II cell; TIII: Type III cell. 


\section{Effect of unilateral and bilateral eyestalk ablation on histology of androgenic gland during active phase}

The structure of AG in unilateral eyestalk ablated males was not different from the intact controls and displayed histological features as described for controls. No significant change was noticed in the thickness of the connective tissue layer $(20.75 \pm 2.11 \mu \mathrm{m})$ or gland width $(267.0 \pm 54.39 \mu \mathrm{m})$ (Figure 3). Proportion of the cell types was comparable to that of controls (type I 27.8 $\pm 2.38 \%$; type II $61.40 \pm 4.21 \%$ and type III $10.80 \pm 3.19 \%$ ) (Figure 2).

The results of bilateral eyestalk ablation during active phase revealed hypertrophy and hyperplasia of the gland. The gland was seen attached firmly on the wall of the PVD and reached its maximum size $(396.96 \pm 70.61 \mu \mathrm{m})$. The gland appeared as an elongated structure with compactly packed cells, covered externally by a distinct connective tissue layer $(23.05 \pm 2.71 \mu \mathrm{m})$. The component cells had dense granular cytoplasm and their size along with the diameter of nuclei increased significantly. Cells were larger with hypertrophied cytoplasm in the AG of bilaterally ablated crabs. All the three cell types were perceptible within the gland. The cells were compact with sharp boundaries and tightly packed without intercellular spaces. The number of type I cells in the bilateral ablated group had increased significantly (58.60 $\pm 4.21 \%)$. The percentage of type II and type III cells was correspondingly less, being $32.80 \pm 4.54 \%$ and $8.60 \pm 2.40 \%$ (Figure 2).

In bilaterally ablated crabs, the gland appeared highly active, elongated and firmly attached to the PVD. Type I cell proliferation was largely observed when compared to AG of -E1 and control crabs. Type I cells $(6.7-13.9 \mu \mathrm{m})$ were oval in shape with distinct cell boundaries (Figure 4). Their nuclei $(4.0-8.1 \mu \mathrm{m})$ were round, mildly basophilic with granular chromatin and occupied a central position. The cytoplasm appeared moderately basophilic and granular in nature. In some type I cells, nuclei showed high basophilia.

Type II cells (13.8-26.2 $\mu \mathrm{m})$ were oval in shape and exhibited large amounts of cytoplasm compared to type I cells. Their nuclei $(2.9-7.2 \mu \mathrm{m})$ were round or oval and eccentric in position. The cytoplasm demonstrated mild basophilia and found granular in nature. In some portions of the gland, type II cells were arranged in lobes. The cells within these lobes showed indistinct cell boundaries. Their oval, moderately basophilic nuclei were seen scattered inside the lobes.

Type III cells (11.0-19.0 $\mu \mathrm{m})$ were less prominently seen than the other two cell types $(8.60 \pm 2.40 \%)$ (Figure 2). There was not much difference in the histological features of type III of -E2 crabs from that of unablated controls.

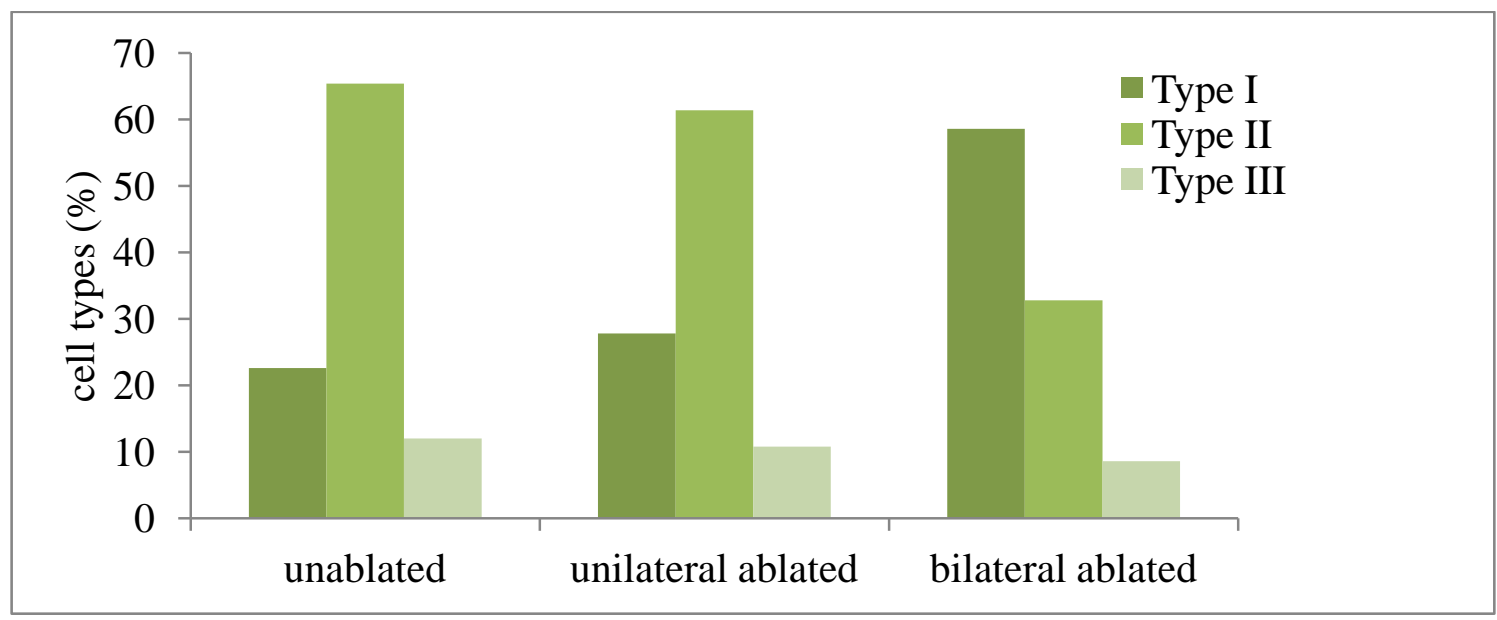

Figure 2. Bar graph representing the proportion of cell types in androgenic gland of unablated, unilateral and bilateral ablated crabs during active phase. 


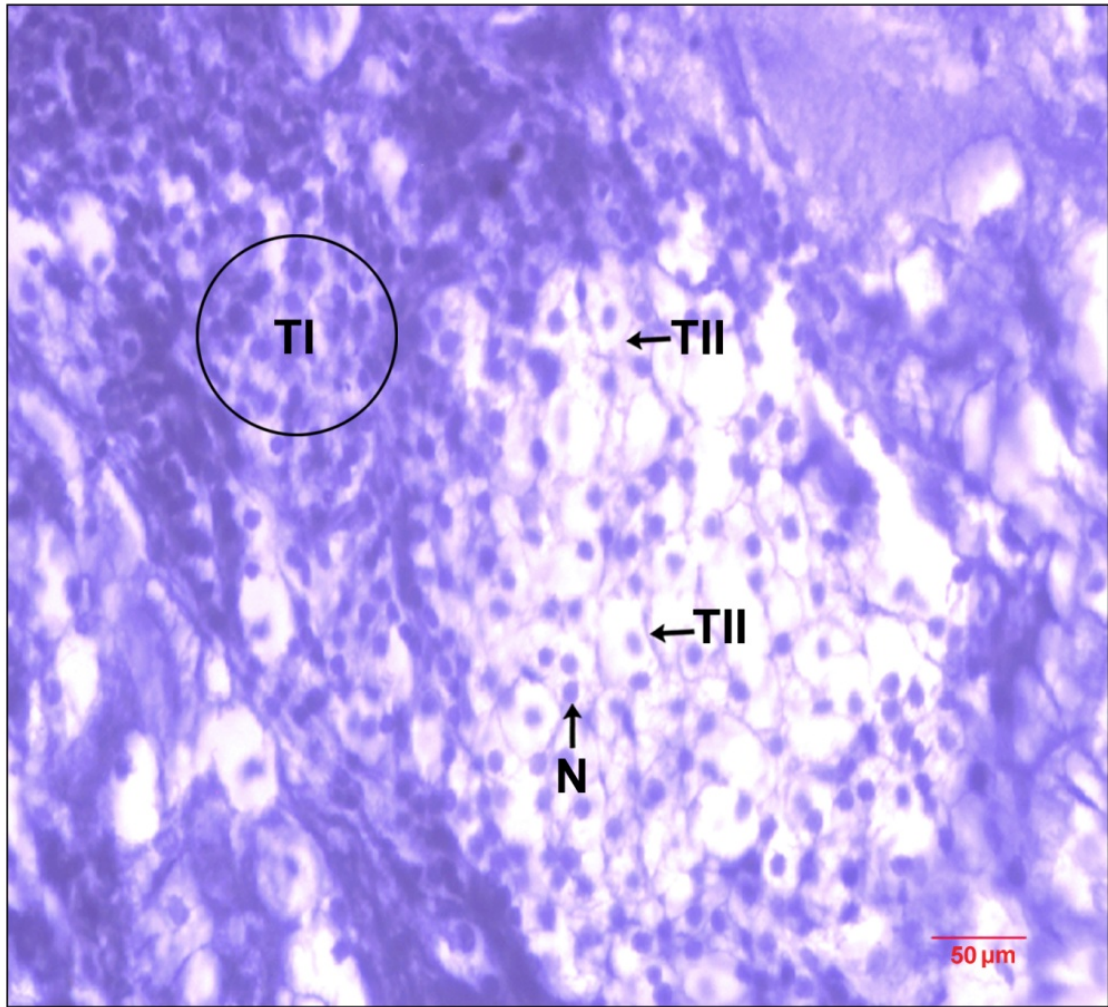

Figure 3. Androgenic gland of unilaterally destalked $T$. schirnerae during active phase (June). TI: Type I cell; TII: Type II cell; N: Nucleus; Cells in circle shows type I proliferation.

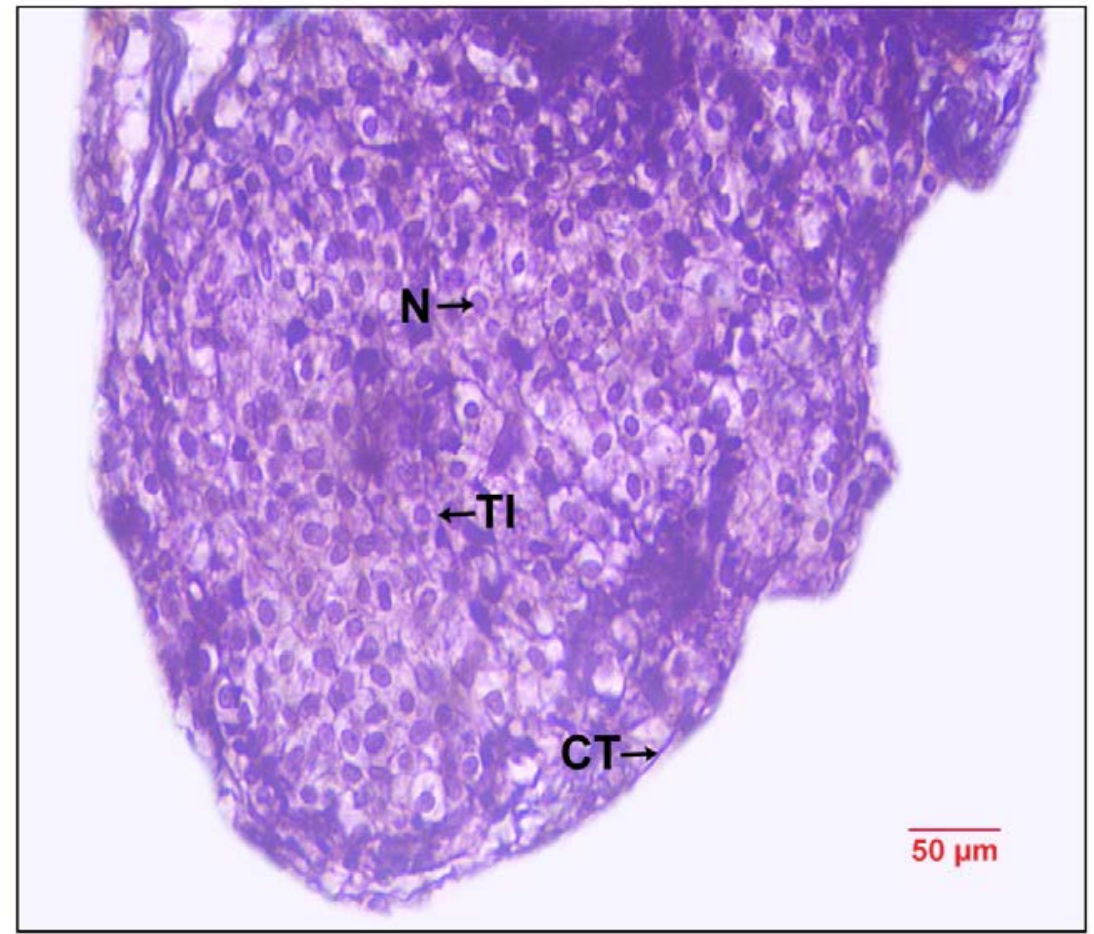

Figure 4. Increased proliferation of type I cells in androgenic gland of bilaterally destalked T. schirnerae during active phase (June). CT: Connective tissue layer; N: Nucleus; TI: Type I cell. 


\section{Histology of androgenic gland of control crabs during revival phase (January-February)}

After a long period of inactivity, the activity of the gland was found revived in January-February with proliferation of type I cells (Figure 5). A gradual increase in the thickness of the connective tissue layer $(14.14 \pm 0.63 \mu \mathrm{m})$ and width of the gland $(209.50 \pm 14.40 \mu \mathrm{m})$ indicated signs of recuperation. The AG was discerned with a few patches of proliferated type I cells scattered among vacuoles and degenerating cells. Type II and III cells were seldom found. Except the small patches of type I cells in some areas, the rest of the gland exhibited signs of degeneration. Cells with indistinct boundaries and degenerated areas were still evident. Many type I cells were observed with intact boundaries. Type II cells with sharp boundaries were hardly perceptible.

Effect of unilateral and bilateral eyestalk ablation on histology of androgenic gland during revival phase

There was not much significant change in the morphology and histology of AG of unilaterally ablated crabs from that of controls during the revival phase (Figure 6). The gland appeared elongated and firmly attached to the PVD. The gland measured 211.66 $\pm 2.14 \mu \mathrm{m}$ wide and the connective tissue layer showed a thickness of $14.53 \pm 0.71 \mu \mathrm{m}$. The gland was seen composed of many patches of polygonal or oval type I cells with distinct cell boundaries.

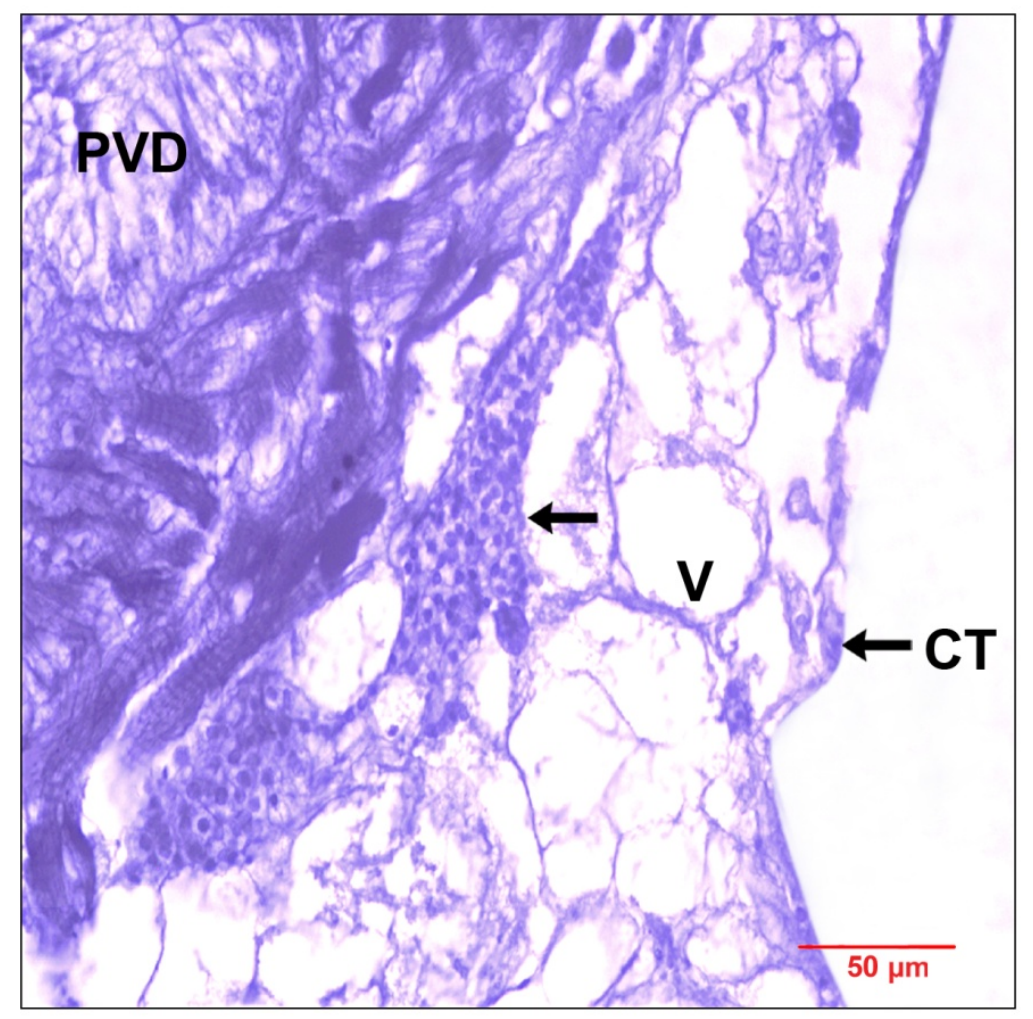

Figure 5. Proliferation of type I cells in the androgenic gland of control crabs during revival phase (January). CT: Connective tissue layer; PVD: Posterior vas deferens; V: Vacuole; Arrow indicates proliferation of type I cells. 


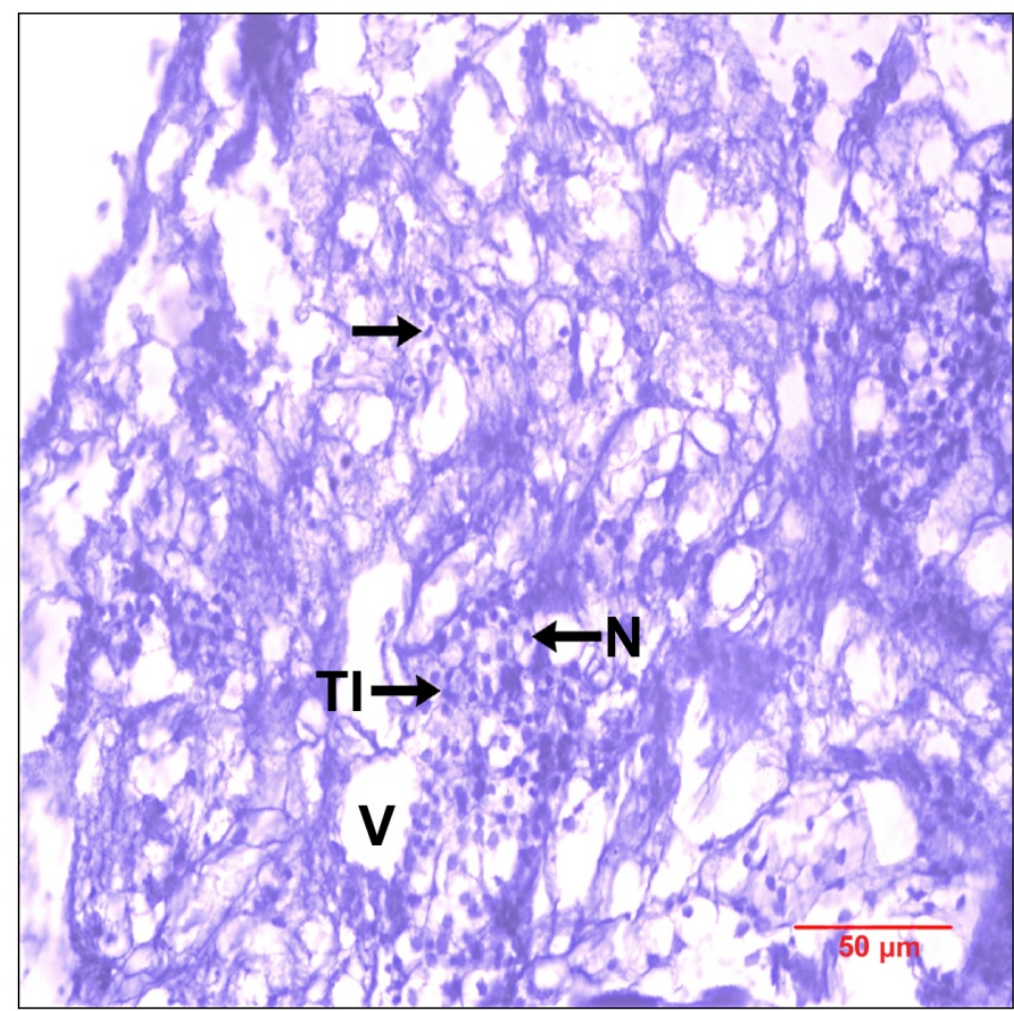

Figure 6. Androgenic gland in unilaterally destalked crabs showing proliferation of type I cells during revival phase (February). N: Nucleus; TI: Type I cell; V: Vacuole; Arrow indicates proliferation of type I cells.

Their large nuclei were round or oval, highly basophilic with granular chromatin and found centrally placed in most of the cells. The cytoplasm showed moderate basophilia. The remaining area in the gland still showed signs of inactivity as indicated by cells with indistinct boundaries, vacuolated appearance and pycnotic nuclei.

The most prominent feature of the AG of bilaterally ablated crabs during revival phase was the extensive proliferation of type I cells. A corresponding increase in width of the gland $(228.57 \pm 43.36 \mu \mathrm{m})$ and thickness of the connective tissue layer $(15.47 \pm 0.86 \mu \mathrm{m})$ was observed in $-\mathrm{E} 2$ crabs of revival phase. Type I cells were polygonal or oval, measuring 2.40-7.20 $\mu \mathrm{m}$ in width. Their nuclei were large, round or oval (1.60-5.30 $\mu \mathrm{m})$ (Figure 7). 


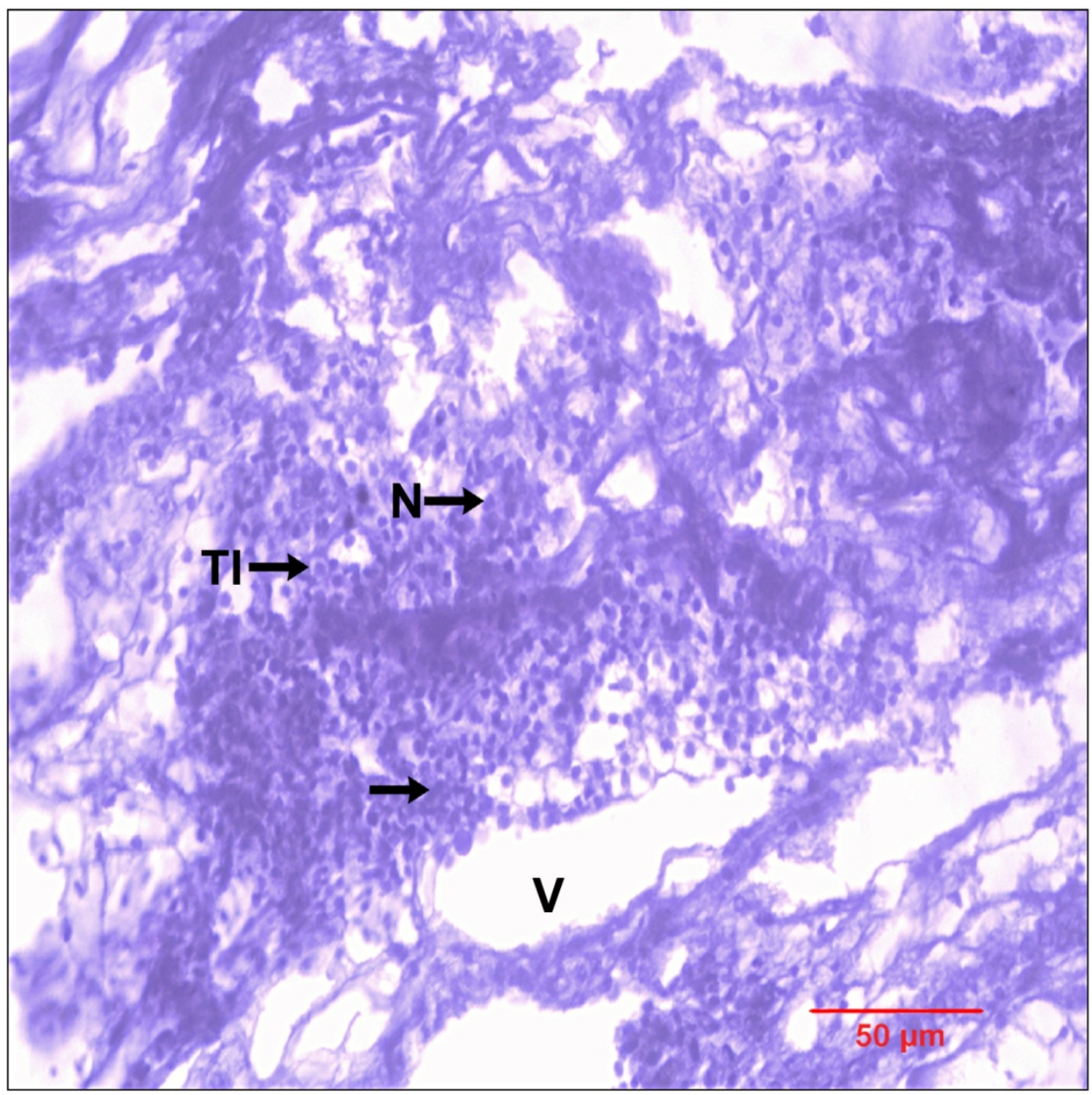

Figure 7. Increased proliferation of type I cells in the androgenic gland due to bilateral eyestalk ablation during the revival phase (February). N: Nucleus; TI: Type I cell; V: Vacuole; Arrow indicates proliferation of type I cells.

\section{Discussion}

In the current investigation,
bilateral eyestalk ablation induced hypertrophy and hyperplasia of the AG during the active phase as evidenced by increase in width of the gland, thickness of the connective tissue layer, increase in cell and nuclear diameter with predominance of type I cells. Comparable results were obtained by Demeusy (1960) in C. maenas where removal of eyestalks led to hypertrophy of the AG, signified by ultrastructural features related to hyperactivity. Removal of eyestalks caused hypertrophy and hyperplasia of the gland in the crabs Scylla serrata, $R$. harrisii, C. sapidus and the shrimp Lysmata seticaudata (Rangnekar et al., 1971; Payen et al., 1971; Touir, 1973). Foulks and Hoffman (1974) observed that destalking led to AG hypertrophy in $P$. platyceros. The structure of AG in $P$. hardwickii on bilateral ablation showed higher activity with hypertrophy and hyperplasia (Kulkarni et al., 1984).

Bilateral destalkation in $P$. hydrodromous resulted in increased length and width of the AG and number of strands constituting the gland, attained a puffy appearance (Adiyodi, 1984). Increased cell and nuclear diameters of the AG was described in -E2 M. lamerrii 15 days post-operation (Sarojini and Gyananath, 1985). Awari and Kiran (1999) observed hypertrophy of AG in eyestalk ablated $M$. rosenbergii compared to intact individuals. Activation of AG has been 
reported in destalked shrimps $P$. canaliculatus (Choy, 1987) and $N$. denticulata (Taketomi et al., 1997). Bilateral extirpation documented hypertrophy supported by increased size and weight of the AG followed by overexpression of polypeptides in $C$. quadricarinatus (Khalaila et al., 2002). Kim et al. (2002) recorded that the AG cells from bilateral eyestalk ablated $M$. nipponense during the reproductively active phase showed highly hypertrophied nuclei, rough endoplasmic reticulum and mitochondria.

Okumura et al. (2005) documented larger AG cells with hypertrophied cytoplasm in bilaterally destalked $P$. hypsinotus. Sroyraya et al. (2010) observed that the AG of bilateral eyestalk ablated $P$. pelagicus underwent hypertrophy with a two-fold increase in the percentage of type I cells compared to the unablated controls. Phoungpetchara et al. (2011) observed AG hypertrophy with proliferation and predominance of type I cells in $M$. rosenbergii subjected to bilateral eyestalk ablation. Vázquez-Islas et al. (2015) recorded a significant rise in the mean cell and nuclear diameters of AG in -E2 intermoult L. vannamei. Hypertrophied AG were also described in eyestalk ablated isopods by Legrand et al. (1968) and Reidenbach (1971). However, in P. kessleri (Aoto and Nishida, 1956), P. borealis (Carlisle, 1959) and L. seticaudata (Charniaux-Cotton, 1960), bilateral eyestalk ablation has not shown any effect on AG activity and spermatogenesis. Studies conducted by Charniaux-Cotton (1965) also revealed that the disappearance of AG was not under the control of eyestalk hormones.

In $T$. schirnerae, unilateral eyestalk ablation during active phase neither caused hypertrophy nor hyperplasia of the gland cells. Revathi et al. (2013) recorded increased number of epithelial cells along with the connective tissue and AG weight in unilaterally eyestalk ablated $M$. rosenbergii. However, Kim et al. (2002) reported that the AG cells of unilaterally destalked $M$. nipponense were quite similar to those of unablated controls. Okumura et al. (2005) have not observed any histological variations in the AG cells of unilaterally ablated $P$. hypsinotus. Sroyraya et al. (2010) reported that the AG in unilateral ablated male $P$. pelagicus was not different from the intact and exhibited histological features as described for controls.

Several authors suggested that the AG is under the control of an inhibitory neuropeptide - GIH, secreted from the XOSG complex of the eyestalks. Demeusy (1953) and Demeusy and Veillet (1958) have observed that secretory activity of the AG is directly regulated by the influence of $\mathrm{GIH}$ in C. maenas. Similar observations were recorded by Hoffman (1968) in $P$. platyceros. Investigations of Kulkarni et al. (1984) suggested that eyestalk hormones have an inhibitory influence on secretory activity of the AG P. hardwickii. Studies of Phoungpetchara et al. (2011) suggested that sinus glands in the eyestalk had some factors that inhibit the activity of the AG, GIH being the most important one. In vitro investigations showed direct inhibition of the AG by sinus gland extracts in $C$. quadricarinatus (Khalaila et al., 2002). Observations of Sarojini and Gyananath (1985) revealed that inhibitory gonadotropins produced from the neurosecretory complex of the eyestalks inhibited testis development and AG activity in M. lamerrii. In P. hydrodromous, Gupta et al. (1989) documented that the inactive phase of the testis is due to increased haemolymph titre of GIH with simultaneous decrease in titres of AGH and gonad stimulating hormone (GSH). Taketomi et al. (1996) and Khalaila et al. (1999) have reported that the onset of spermatogenic processes in the testis is reliant on activities of the androgenic gland.

The importance of secretions from the protocerebrum in the functioning of AG was studied in several crustaceans (Juchault, 1977; Touir, 1977b; Juchault and Legrand, 1978). In isopods, hyperactivity of the gland and precocious differentiation of adult external sexual characters have been noted on removal of various regions of the protocerebrum with or without optic lobectomy (Juchault et al., 1965; Reidenbach, 1966). Brain and thoracic 
ganglia extracts enhanced the spermatogenic activity and corresponding increase in AG activity in $M$. lamerrii (Sarojini and Gyananath, 1985). A stimulatory gonadotropin released from the protocerebrum was reported in the amphipod Orchestia gammarella (BerreurBounenfant, 1967) and P. hydrodromous (Adiyodi and Adiyodi, 1974). Investigations of Kulkarni et al. (1984) suggested that brain and thoracic ganglia hormones have stimulatory influence on the secretory activity of the AG. Ye et al. (2006) observed that co-incubation of brain or thoracic ganglia with AG resulted in significantly enlarged diameter of AG cells, indicating the role of GSH in the development and secretory activity of AG in S. serrata.

In $T$. schirnerae, unilateral ablation was not effective in inducing hypertrophy and hyperplasia of the AG during the active phase, probably because the unilateral eyestalk ablated crabs may still receive the inhibitory control from the remaining intact eyestalk, causing the AG to remain analogous to that of the unablated control crabs. Our research is in agreement with the findings of Okumura et al. (2005) in $P$. hypsinotus and Sroyraya et al. (2010) in $P$. pelagicus subjected to unilateral destalkation. In bilaterally eyestalk ablated crabs, this inhibition is completely cut off resulting in hypertrophy and hyperplasia.

In the present investigation, bilateral destalkation induced hypertrophy and hyperplasia was not followed by secretory activity of the gland during the active phase; which possibly suggests the non-functional nature of hypertrophy and hyperplasia of the AG. Likewise, hypertrophy of the gland under eyestalk removal is apparently of the non-functional type in $P$. borealis (Charniaux-Cotton, 1967). Adiyodi (1984) reported that AG hypertrophy was not accompanied by any visible hypersecretory activity from 20 to 30 days after destalkation in adult $P$. hydrodromous. On the other hand, ultrastructural observations in hypertrophied AG in optic lobectomized $C$. maenas seemed to contradict the view that in such forms hypertrophy is a consequence of hypersecretion (Meusy, 1965). The bilateral destalkation induced hypertrophy and hyperplasia of AG in T. schirnerae may be a consequence of cells synthesizing proteins for their own use and not for secretion. In destalked C. maenas, Meusy (1965) reported that only the growth of AG and not the secretory activity was permanently stimulated. Hypersecretion not accompanied by hypertrophy has been reported in the isopod Idotea deprived of optic lobes and median protocerebrum (Reidenbach, 1966).

In conclusion, bilateral eyestalk ablation of $T$. schirnerae during active phase of the androgenic gland induced hypertrophy and hyperplasia as evidenced by increased width of the gland, thickness of the connective tissue layer, increase in cell and nuclear diameter with predominance of type I cells. Unilateral destalkation during active phase neither caused hypertrophy nor hyperplasia of the gland cells probably because the inhibitory principle from the remaining intact eyestalk allowed the gland to remain analogous to that of the unablated controls. During revival phase, the most prominent feature of the gland of bilaterally ablated crabs was the extensive proliferation of type I cells. Unilateral destalkation did not induce much significant change in the morphology and histology of the gland during revival phase.

\section{Conflict of interest statement}

Authors declare that they have no conflict of interests.

\section{References}

Adiyodi, R. G. Seasonal changes and the role of eyestalks in the activity of the androgenic gland of the crab, Paratelphusa hydrodromous (Herbst). Comp. Physiol. Ecol., v. 9, p. 427431, 1984.

Adiyodi, K. G.; Adiyodi, R. G. Endocrine control of reproduction in decapod Crustacea. Biol. Rev., v. 45, p. 121-165, 1970. http://10.1111/j.1469-185X.1970.tb01627.x

Adiyodi, K. G.; Adiyodi, R. G. Comparative physiology of reproduction in arthropods. Adv. Comp. Biochem. Physiol., v. 5, p. 37-107, 
1974. http://dx.doi.org/10.1016/B978-0-12011505-1.50008-6

Aoto, T.; Nishida, H. Effect of removal of the eyestalks on the growth and maturation of oocytes in a hermaphroditic prawn Pandalus kessleri. J. Fac. Sci., Hokkaido University, Series VI, v. 12, p. 412-424, 1956.

Awari, S. A.; Kiran, D. Histological and histochemical study of androgenic gland of Macrobrachium rosenbergii (de Mann). J. Aquacult. Trop., v. 14, p. 101-112, 1999.

Berreur-Bonnenfant, J. Action de la glande androgene et du cerveau sur la gamatogenese de Crustaces Peracarides. Arch. Zool. Exp. Gen., v. 108, p. 521-558, 1967.

Carlisle, D. B. On the sexual biology of Pandalus borealis (Crustacea, Decapoda). The termination of the male phase. J. Mar. Biol. Assoc. UK, v. 38, p. 481-491, 1959.

Charniaux-Cotton, H. Sex determination. In: Waterman, T. H. (Ed.). The Physiology of Crustacea. New York: Academic Press, 1960. v. I.

Charniaux-Cotton, H. Hormonal control of sex Differentiation in invertebrates. In: De Haan, R. L.; Ursprund, H. (Eds.). Organogenesis. New York: Academic Press, 1965. p. 701-740.

Charniaux-Cotton, H. Arrét de la spermatogenèse chez la Crevette Pandalus borealis (Krøyer) après ablation des pédoncules oculaires. C. R. Acad. Sci. D, v. 161, p. $2100-$ 2104, 1967.

Charniaux-Cotton, H.; Payen, G. Sex differentiation. In: Bliss, D. E.; Mantel, L. H. (Eds.). The Biology of Crustacea. New York: Academic Press, 1985. p. 217-299.

Charniaux-Cotton, H.; Payen, G. Crustacean reproduction. In: Laufer, H.; Downer, R. G. H. (Eds). Endocrinology of selected invertebrate types. New York: Alan R. Liss, 1988. p. 279303.

Choy, S. C. Growth and reproduction of eyestalk ablated Penaeus canaliculatus (Crustacea: Penaeidae). J. Exp. Mar. Biol. Ecol., v. 112, p. 93-107, 1987. http://dx.doi.org/10.1016/0022-0981(87)90111-0

Chung, J. S.; Manor, R.; Sagi, A. Cloning of an insulin-like androgenic gland factor (IAG) from the blue crab Callinectes sapidus: implications for eyestalk regulation of IAG expression. Gen. Comp. Endocrinol., v. 173, p. 4-10, 2011. http://dx.doi.org/10.1016/j.ygcen.2011.04.017
Demeusy, N. Effets de l'ablation des pedoncules oculaires sur le developpement de l'appareil genital mâle de Carcinus maenas Pennant. C. R. Acad. Sci. D, v. 236, p. 974975, 1953.

Demeusy, N.; Veilet, A. Influence de l'ablation des pedoncules oculaires sur la glande androgene de Carcinus maenas. C. R. Acad. Sci. D, v. 246, p. 1104-1107, 1958.

Demeusy, M. N. Differenciation des voies genitales males du crabe Carcinus maenas Linne. Role des pedoncules oculaires. Cah. Biol. Mar., v. 1, p. 259-277, 1960.

Devi, A. R. S.; Smija, M. K. Seasonal changes in the structure and secretory activity of the androgenic gland of Travancoriana schirnerae. Cent. Eur. J. Biol., v. 9, p. 70-79, 2014. http://dx.doi.org/10.2478/s11535-013-0180-7

Erkan, M.; Tunali, Y.; Ekinci, S.; Kara, S. Histology of the androgenic gland in Eriphia verrucosa (Forskal, 1775) (Decapoda, Brachyura). Turk. J. Zool., v. 33, p. 79-84, 2010. http://dx.doi.org/10.3906/zoo-0808-24

Fingerman, M. Roles of neurotransmitters in regulating reproductive hormone release and gonadal maturation. Invertebr. Reprod. Dev., v. 31， p. 47-54, 1997. http://dx.doi.org/10.1080/07924259.1997.9672562

Foulks, N. B.; Hoffman, D. L. The effects of eyestalk ablation and $\beta$-ecdysone on RNA synthesis in the androgenic glands of the protandric shrimp, Pandalus platyceros (Brandt). Gen. Comp. Endocrinol., v. 22, p. 439-444, 1974. http://dx.doi.org/10.1016/00166480(74)90018-5

Fowler, R. J.; Leonard, B. V. The structure and function of the androgenic gland in Cherax destructor (Decapoda: Parastacidae). Aquaculture, v. 171, p. 135-148, 1999. http://dx.doi.org/10.1016/S00448486(98)00416-5

Ginsburger-Vogel, T.; Charniaux-Cotton, H. Sex determination. In: Abele, L. G. (Ed.). The Biology of Crustacea, New York: Academic Press, 1982. v. 2. p. 257-281.

Gupta, N. V. S.; Kurup, K. N. P.; Adiyodi, R. G.; Adiyodi, K. G. The antagonism between somatic growth and testicular activity during different phases in intermolt (stage C4) in sexually mature freshwater crab Paratelphusa hydrodromous. Invertebr. Reprod. Dev., v. 16, p. 195-203, 1989. http://dx.doi.org/10.1080/07924259.1989.9672077 
Hasegawa, Y.; Hirose, E.; Katakura, Y. Hormonal control of sexual differentiation and reproduction in Crustacea. Amer. Zool., v. 33, p. 403-411, 1993.

Hoffman, D. L. Seasonal eyestalk inhibition on the androgenic glands of a protandric shrimp. Nature, v. 218, p. 170-172, 1968. http://dx.doi.org/10.1038/218170a0

Joshi, P. C.; Khanna, S. S. Studies on the androgenic gland of the freshwater crab Potamon koolooense (Rathbun). Z. Mikrosk. Anat. Forsc., v. 4, p. 699-713, 1987.

Juchault, P. Correlation entre differenciation sexuelle male externe et function androinhibitrice de la region mediane du protocerebron chez le crustace, Sphaeroma serratum. C. R. Acad. Sci. D, v. 285, p. 179182, 1977.

Juchault, P.; Legrand, J. J.; Mocquard, J. P. Mise en evidence d'une inhibition protocérébrale de la glande androgène et de la croissance des variants sexuels mâles chez l'Oniscoide Porcellio dilatatus Brandt. C. R. Acad. Sci. D, v. 261, p. 1116-1118, 1965.

Juchault, P.; Legrand, J. J. Study of the functioning of the androgenic gland in the case of cross grafts between two terrestrial isopod crustacean species, Porcellio dilatatus and Armadillidium vulgare: notion of a hormone specificity in control of androgenic gland function. Gen. Comp. Endocrinol., v. 36, p. 175-186, 1978. http://dx.doi.org/10.1016/00166480(78)90020-5

Katakura, Y. Sex differentiation and androgenic gland hormone in the terrestrial isopod Armadillidium vulgare. Sym. Zool. S. Lon., v. 53, p. 127-142, 1984.

Katakura, Y. Endocrine and genetic control of sex differentiation in the malacostracan Crustacea. Invertebr. Reprod. Dev., v. 16, p. 177-181, 1989. http://dx.doi.org/10.1080/07924259.1989.9672075

Khalaila, I.; Weil, S.; Sagi, A. Endocrine balance between male and female components of the reproductive system in intersex Cherax quadricarinatus (Decapoda: Parastacidae). J. Exp. Zool., $\quad$ v. 283, p. 286-294, 1999. http://dx.doi.org/10.1002/(SICI)1097010X(19990215)283:3

Khalaila, I.; Manor, R.; Weil, S.; Granot, Y.; Keller, R.; Sagi, A. The eyestalk-androgenic gland-testis endocrine axis in the crayfish Cherax quadricarinatus. Gen. Comp. Endocrinol., v. 127, p. 147-156, 2002. http://dx.doi.org/10.1016/S00166480(02)00031-X
Kim, D. H.; Jo, Q.; Kim, B. K.; Han, C. H. Eyestalk ablation-induced androgenic gland activity and gonad development in the freshwater prawn Macrobrachium nipponense (De Haan, 1849). Invertebr. Reprod. Dev., v. 42, $\quad$ p. 35-42, 2002. http://dx.doi.org/10.1080/07924259.2002.9652507

Kulkarni, G. K.; Nagabhushanam, R.; Joshi, P. K. Neuroendocrine control of reproduction in the male penaeid prawn, Parapenaeopsis hardwickii (Miers) (Crustacea, Decapoda, Penaeidae). Hydrobiologia, v. 108, p. 281-289, 1984. http://dx.doi.org/10.1007/BF00006337

Legrand, J. J.; Juchault, P.; Mocquard, J. P.; Noulin, G. Contribution à l'étude du contrôle neurohumoral de la physiologie sexuelle mále chez les Crustacés Isopodes terrestres. Ann. Embryol. Morphol., v. 1, p. 97-105, 1968.

Meusy, J. J. Modification ultrastructurales des glandes androgènes de Carcinus maenas $\mathrm{L}$. (Crustacé Décapode) consecutives de l'ablation des pédoncules oculaires. C. R. Acad. Sci. D, v. 26, 5901-5904, 1965.

Okumura, T.; Nikaido, H.; Yoshida, K.; Kotaniguchi, M.; Tsuno, Y.; Seto, Y.; Watanabe, T. Changes in gonadal development, androgenic gland cell structure and hemolymph vitellogenin levels during male phase and sex change in laboratory-maintained protandric shrimp, Pandalus hypsinotus (Crustacea: Caridea: Pandalidae). Mar. Biol., v. 148, p. 347-361, 2005. http://dx.doi.org/10.1007/s00227-005-0073-7

Payen, G.; Costlow, J. D.; Charniaux-Cotton, H. Etude comparative de l'ultrastructure des glandes androgènes de crabs normaux et pédonculectonisés pendant la vie larvaire ou aprés la puberté chez les espèces: Rhithropanopeus harrisii (Gould) et Callinectes sapidus Rathbun. Gen. Comp. Endocrinol., v. 17, p. 526-542, 1971. http://dx.doi.org/10.1016/0016-6480(71)90187-0

Phoungpetchara, I.; Tinikul, Y.; Poljaroen, J.; Chotwiwatthanankun, C.; Vanichviriyakit, R.; Sroyraya, M.; Hanna, P. J.; Sobhon, P. Cells producing insulin-like androgenic gland hormone of the giant freshwater prawn, Macrobrachium rosenbergii, proliferate following bilateral eyestalk-ablation. Tissue Cell, v. 43, p. 165-177, 2011. http://dx.doi.org/10.1016/j.tice.2011. 02.001

Rangnekar, P. V.; Madhyastha, M. N.; Latey, A. N. Hormonal control of reproduction in the male crab, Scylla serrata (Forskal). J. Anim. Morphol. Physiol., v. 18, p. 17-29, 1971. 
Reidenbach, J. M. Mise en évidence d'une intervention du complexe neurosécréteur céphalique dans la physiologie sexuelle male chez le Crustacé Isopode marin Idotea balthica blasteri Audouin. C. R. Acad. Sci. D, v. 262, p. 682-684, 1966.

Reidenbach, J. M. Les méconismes endocriniens dans le contrôle de la différenciation du sexe, la physiologie sexuelle et la mue chez le Crustacé Isopode marin: Idotea balthica (Pallas). Nancy: Univ. de Nancy I, 1971. (Th. Doct. Etat $n^{\circ}$ CNRS: AO-4874).

Revathi, P.; Iyapparaj, P.; Vasanthi, L. A.; Jeyanthi, S.; $\quad$ Sankaralingam, S.; Ramasubburayan, R.; Prakash, S.; Krishnan, M. Impact of eyestalk ablation on the androgenic gland activity in the freshwater prawn Macrobrachium rosenbergii (De Man). World J. Fish. Mar. Sci., v. 5, p. 373-381, 2013. http://dx.doi.org/10.5829/idosi.wjfms.2013.05.0 4.731

Sagi, A.; Anir, E.; Khalaila, I. Sexual differentiation in decapod crustaceans: role of the androgenic gland. Invertebr. Reprod. Dev., v. 31, $\quad$ p. 55-61, 1997. http://dx.doi.org/10.1080/07924259.1997.9672563

Sarojini, R.; Gyananath, G. Seasonal variations and the role of neurosecretory hormones on the androgenic gland of the prawn Macrobrachium lamerrii. Proc. Anim. Sci., v. 94, p. 503-508, 1985. http://dx.doi.org/10.1007/BF03186359

Sroyraya, M.; Chotwiwatthanakun, C.; Stewart, M. J.; Soonklang, N.; Kornthong, N.; Phoungpetchara, I.; Hanna, P. J.; Sobhon, P. Bilateral eyestalk ablation of the blue swimmer crab, Portunus pelagicus, produces hypertrophy of the androgenic gland and an increase of cells producing insulin-like androgenic gland hormone. Tissue Cell, v. 42, p. 293-300, 2010. http://dx.doi.org/10.1016/j.tice.2010.07.003

Sun, P. S.; Weatherby, T. M.; Dunlap, M. F.; Arakaki, K. L.; Zacarias, D. T.; Malecha, S. R. Developmental changes in structure and polypeptide profile of the androgenic gland of the freshwater prawn Macrobrachium rosenbergii. Aquacult. Int., v. 8, p. 327-334, 2000. http://dx.doi.org/10.1023/A:1009205027360
Taketomi, Y.; Nishikawa, S.; Koga, S. Testis and androgenic gland during development of external sexual characteristics of the crayfish Procambarus clarkii. J. Crust. Biol., v. 16, p. 24-34, 1996.

Taketomi, Y.; Nishino, M.; Yoshizumi, K. Effects of eyestalk hormone on the androgenic gland of the shrimp Neocaridina denticulata. Proc. XIIIth Internatl. Congress Comp. Endocrinol., p. 79-82, 1997.

Thampy, D. M.; John, P. A. The androgenic gland of the shrimp Palaemon dayanus. Mar. Biol., $\quad$ v. 12, $\quad$ p. 285-288, 1972. http://dx.doi.org/10.1007/BF00366327

Touir, A. Influence de l'ablation des pedoucules oculaires su les glandes androgenes, les gonades, les caracteres sexuels externes males et l'inversion sexuelle chez la Crevette hermaphrodite Lysmata seticaudata Risso. C. R. Acad. Sci. D, v. 277, p. 2441-2544, 1973.

Touir, A. Donnees nouvelles concernant l'endocrinologie sexuelle des Crustaces Decapodes Natantia hermaphrodites et gonochoriques. I. Maintien des glandes androgenes et role de ces glandes dans le controle des gametogeneses et des caracteres sexuels extrenes males. B. Soc. Zool. Fr., v. 102, p. 375-400, 1977a.

Touir, A. Donne esnouvelles concernant l'endocrinologie sexuelle des Crustaces Decapodes Natantia hermaphrodites et gonochoriques. II. Maintien des gonies et evolution des gametogeneses in vivo et in vitro. C. R. Acad. Sci. D, v. 284, p. 2515-2518, 1977b.

Vázquez-Islas, G.; Guerrero-Tortolero, D. A.; Garza-Torres, R.; Álvarez-Ruiz, P., Mejía-Ruiz, H.; Campos-Ramos, R. Quantitative analysis of hypertrophy and hyperactivity in the androgenic gland of eyestalk-ablated male Pacific white shrimp Litopenaeus vannamei during molt stages. Aquaculture, v. 439, p. 7-13, 2015. http://dx.doi.org/10.1016/j.aquaculture.2015.01. 015

Ye, H.; Huang, H.; Li, S.; Wang, G.; Li, Q. In vitro study of neuroendocrine regulation over the testicular development in mud crab Scylla serrata. Chin. J. Oceanol. Limnol., v. 24, p. 142-146, 2006.

License information: This is an open-access article distributed under the terms of the Creative Commons Attribution License, which permits unrestricted use, distribution, and reproduction in any medium, provided the original work is properly cited. 